\title{
Traditional Stories Kuburan Duo as a Means of Transmission Culture to Create Student's Character in SMAN 1 Lubuk Sikaping
}

\author{
Ririn Rizana ${ }^{1, *}$ Amril Amir ${ }^{1,}$ Erizal Gani ${ }^{1}$ \\ ${ }^{1}$ Indonesian Language Department, Universitas Negeri Padang, Padang, Indonesia \\ *Corresponding author.E-mail:rizanaririn482@gmail.com
}

\begin{abstract}
This research is a type of qualitative research obtained through interviews with informants. The main purpose of this study is to find out the values contained in the traditional story "Kuburan Duo" for the formation of children's character. The research was conducted at SMA 1 Lubuk Attitude. The results of this study are the content of character values, namely (1) individual moral values, (2) social moral values, and (3) religious moral values. First, the individual's moral values are (a) respect and appreciate, (b) fair and wise, (c) know how to repay, and (d) be careful in acting. Second, the social moral values contained are (a) working together, (b) compassion, (c) harmony, and (d) caring about the fate of others. Third, the religious moral values contained are (a) surrender to God and (b) ask for God's forgiveness.
\end{abstract}

Keywords: Traditional Stories, Duo Graves, Children's Characters

\section{PRELIMINARY}

Today, traditional stories have begun to be abandoned. Even children and adults often forget the traditional stories they learned first. Adults give them other games rather than traditional stories. Traditional stories that are instilled in children from an early age have faded. It could be that the story has been broken up in their parents' generation. This is what causes the times already modren . Children at the age of three are now active and familiar with electronic devices such as cellphones , laptops, computers, and can even beat adults in tinkering with these electronic devices. They don't even need to be taught how to operate the tool. Children today easily catch and learn quickly. So parents and adults don't need to be surprised anymore if they see children with these skills have been adept at playing electronic instruments that sometimes even adults still need several times to learn it. Or their patterns and behavior are not appropriate for their age. That's what we see a lot today, the more advanced patterns and lifestyles make them smarter.

The era that has been growing and changing contains us, of course, we cannot avoid it. Getting a sophisticated tool leads everyone to be able to use it. These sophisticated tools can make children learn to be more active and creative in using them. Likewise, there are many various modern and traditional stories that can be known.

When our parents were young, the world of stories was a world that made them feel entertained. It was as if the stories or tales they heard made them feel like they were playing. Even in ancient times stories were considered solace, giving happiness to their listeners. Their grandmother who told the story was so excited that she felt like she was in the fairy tale.

Telling or telling folklore is a story that is heard for the royal family. Is a separate entertainer for the royal family. Even in ancient times the folklore pen at that time was valued until it received an honorary title from the kingdom. With the times that have changed, stories or folk tales no longer belong to the kingdom. Even people can tell stories or listen to traditional stories. Stories can be found today in various places such as television, radio, youtube, and others. Similarly, if we meet at school for students, stories or folklore are more fun for them when compared to lessons. They will be happy and enjoy stories they have never heard of.

A story will have meaning if we can find the meaning behind the story or folklore that is heard. People today will believe in stories or folk tales, because they believe that these stories have their own meaning and meaning. It could be that one of the stories or folk tales they heard had been experienced. 
Sauri and Purlilaiceu [1] said that the results of the folklore inventory can be used as learning materials. Literary works can foster understanding, appreciation, sensitivity, critical thinking, and sensitivity to good feelings towards the environment. Likewise, the benefits of folklore for children's characters. The formation of children's character cannot be done in a short time. It takes a long process in a long time and is carried out continuously and the most important thing is the use of appropriate and effective methods. One of the ways and one of the fun things that can be used to shape children's character is through stories [2].

According to Megawangi [3], pioneer of holistic character education, in the formation of children's character there are three things that must take place in an integrated manner. First, children understand good and bad, understand what actions to take, and are able to give priority to good things. Second, have a love for good and hate bad deeds. This love is a torch or passion to do good things.

Folklore is included in the science of folklore. Dananjaya [4] states that folk is a synonym of collective, which also has the same physical or cultural identifying characteristics, and has an awareness of personality as a community unit. Lore is a folk tradition, which is part of a culture that is passed down from generation to generation orally or through examples accompanied by gestures or mnemonic devices.

Lizawati [5] reveals that folklore that is heard will indirectly shape the attitude and morals of the child. Folklore is not only a bedtime story, it can even shape children's morals. Parents can try it at the time of putting their children to sleep which is accompanied by children's stories, especially folk tales. A mother who lulls her child has a very big influence. Through a mother's embrace and physical touch, there is a kind of longing for children to their parents. This is the basis for harmonious relationships within the family. In this regard, children must be introduced to God from an early age. That way, emotional closeness will be created between mother and child without overriding the role of the father. [6]

Folklore is also included in literary works that are conveyed by parents orally to children. One of the ways to make folklore is to build children's character because in folklore there are characters in which the character has a character and personality that can be imitated or can be a lesson for a child [7].

Culture is an activity that is patterned from human behavior in society providing the results of his work with ideas, values, norms, regulations [8]. The values contained in stories or fairy tales develop and have a culture that is beneficial for early childhood. The application of values, courtesy and compassion for others begins to fade from generation to generation. This gives rise to evidence that the role of education has not been optimally able to build good character. Kurniawan [9] mentions that education functions to make humans as complete beings and upholds human values and liberates humans in all aspects. In connection with this, the nation's character education development program is non-negotiable because a nation that has faded its original character and character will lose its identity and will continue to be in a slump [10].

\section{THEORETICAL REVIEW}

\subsection{Cultural Transmission}

Culture is an activity that is patterned from human behavior in society providing the results of his work with ideas, ideas, values, norms, regulations, [11]. Cultural inheritance is included in Cultural Transmission which is knowledge and experience that can be used as a guide and successor of culture. Cultural transmission does not only convey or provide a material but also conveys values that are guided by society.

Culture can teach new generations how to behave in society. The means of transmitting and transforming culture are schools and families. Where schools have a role in education to function for the next generation, it can also transform with the development of the current era.

1. Family Education Environment

In the family, the identification process allows us to get to know other family members, both those who have been around us and those outside the city. The purpose of cultural transmission is to provide information that can encourage and provide changes that are around them. Efforts to encourage these provide experience, knowledge and ways in implementing learning that are adapted to education and culture in the family environment. The most important thing in getting education and teaching is in the family environment.

2. Community Education Environment

Society is a group of people who have a tradition to live together. In a community environment will be formed if a group of people come and cooperate to settle down. This cultural transmission or cultural inheritance has a social role, including the kinship system and education.

3. School Education Environment

School is a means that also influences the environment. Creating learning in training 
intelligence, and creating good morals. Society categorizes education as formal advice. Teachers teach the values and designs that are embraced in the community. The process of inheritance in schools is carried out in a planned and continuous manner.

4. Media Education Environment

Spreading news, opinions, knowledge is a part of society. Getting interesting and actual news is the nature of mass media. The mass media also affects various deviations from the values and norms and rules that exist in society. Mass media is one of the means in the community.

\subsection{Character building}

The world of education cannot be separated from the problem of morality. Virtue, good manners, polite language and other positive things will give birth to good and commendable morals. Smart and skilled alone is not enough. Cleverness, intelligence or genius will give birth to despicable things if they are not balanced by good morals. High skills or skills, and not based on commendable character, will produce harmful and destructive works.

The term character is often associated and interchanged with the term ethics, morals, and/or values. The limitation of the term character turns out to be very varied according to the point of view of the limitation. Character can also be translated as innate, heart, soul, personality, character, behavior, personality, nature, character, temperament, character. Character means personality, behavior, character, character, and character.

In the context of the history of education in Indonesia, the importance of character education as the development of the nation's superior generation. Making a student or student to have a superior character is not easy, as is turning the palm of the hand. It is even more difficult if the negative character of students has been formed from the family environment of the community. However, it does not mean that the educational process cannot shape the superior character of students.

Sumiyati [12] said that character education through cultural values that are in accordance with the child's condition has not yet received attention from parents and teachers. Character education carried out by parents and teachers in schools adopts the theory of character education in books and only teaches it as a theory, not practice. In this case Ratna [13], the role of the character in character education has the most important elements: a. In the elements of character and characterization there are various problems related to character and characterization.

b. Associated with other disciplines, in this connection the character education of characters and characterizations is most easily recognized so that it is easier to apply, and

c. Characters and characterizations relate to oneself, to the reader's self so that it is easier to understand.

\subsection{Synopsis of the Pasaman Traditional Story "Kuburan Duo"}

One of the traditional story in Pasaman that can be transmitted in shaping the character of children one of which is the "Graveyard Duo" .Starting from two brothers with different languages and different villages. In an area located in the area Cubadak precisely in Pasaman, the stay was two brothers that came from Minang and BatakMandailing. One day the two brothers wanted to hunt and animals Meet the deer, they negotiate and the BatakMandailing said "Sabariba in au, Sabariba in ho" means half for me and half for you . Of course with language BatakMandailing had made the Minang people do not understand the point. But there was an agreement between the two brothers.

When they got the deer, the conversation between these two languages that did not understand each other emerged. The part that the Tapanuli people want to take is the deer's head while the Minang people also want the head. The MandailingBatak people say " Ulunaitapardua" but the Minang people do not understand what the MandailingBatak people mean by using their respective languages.

"Indak, be patient in the ang, be patient with the deck den, " said the Minang people. Answer the Mandailing "Olo!", only Minang people think "Olo" is crazy. Then the emotions of the Minang people were chased and beaten by the Mandailing people. Because the Mandailing people hit him saying " mancit", for the Mandailing language, mancit means sick. It is thought that the Minang people abuse the language by saying the Minang people are mancit which means rat.

Words defined in B atak make the Minang temper and emotions. The words they say are interpreted in their respective languages, so that a fight occurs, until it ends in killing and killing. That's why in the CubadakPasaman area there is a duo's grave that is juxtaposed together.

\section{RESEARCH METHODS}

The research method is a series of ways of working so that a research can be structured, valid, logical, and 
directed. The research method in this study consists of the following stages.

\subsection{Research Type}

This type of research is a qualitative research. This study focused on the process and pemakaan so that the data produced in the form of descriptive text, such as information oral and written from the object of study [14].

\subsection{Data and Data Sources}

The data of this research are the words contained in the folklore of the Pasaman area, namely the folklore "Kuburan Duo". The data source is a reference to the data so that it is valid and valid. This folklore is referred to from informants in the Pasaman area who believe in the truth of the "Kuburan Duo" folklore. According to Sugiyono [14], there are several considerations in determining the key informants .

1. Informants must be in accordance with the object of research, one of which is the determination of age.

2. Informants are judged to be able to represent the population as a whole.

3. Informants are judged to have mastered the object of study based on several conditions so that the data is considered valid.

Based on these criteria, in this study, the researcher selected four (4) research informants with details: 2 early adults (20-40) and 2 late adults (40-60). Informants were also taken from the distribution of several villages evenly so that the folklore "Kuburan Duo" is not made up. The selection of informants was also adjusted to the knowledge of the informants, namely people who had long lived in the research location and controlled the research area.

\subsection{Data collection method}

1. Observation

Before recording the folklore "Kuburan Duo", the researchers first made observations to check the location of the two graves which are evidence of the existence of this folklore. The researcher also observed the people living around the graves to ask people's beliefs about the "Kuburan Duo" folklore.

2. Interview

Interviews were conducted with selected data sources (informants) and the results were then recorded. Recording the results of interviews conducted by way of note in writing and by recording through video and audio recordings.

3. Literature review

In this study, the researchers referred to various sources related to the concept of folklore, oral literature, child psychology, character education, social learning, and moral and religious values.

\section{RESULTS AND DISCUSSION}

\subsection{Analysis of the Folklore "Duo's Grave" on} Children's Characters

According to Sulistyarini [15], folklore contains the noble values of the nation, especially the values of character and moral teachings. Folklore contains various moral values, namely as follows.

1. Values of individual moral include (1) compliance, (2) courage, (3) sacrifice, (4) honest, (5) fair and reasonable, (6) honor and respect, (7) working hard, (8) keep promises, (9) know how to repay, (10) be humble, and (12) be careful in acting.

2. Values-values social morals include: (1) collaboration, (2) helpful, (3) affection, (4) harmony, (5) likes to give advice, (6) care about the fate of others, and (7) likes to pray for others.

3. Values-religious moral values include (1) believe in the power of God, (2) believes in God, (3) surrender to God or trust, and (4) beg God for forgiveness.

Based on the opinion of Sulistyarini (2006), the moral values that can be taken from the folklore "Kuburan Duo" in Pasaman are as follows.

1. Individual Moral Values

The sibling characters in the folklore "Kuburan Duo" should have an attitude of mutual respect and appreciation. The language difference that occurs is indeed the core factor of the misunderstanding, but it would be nice if the two characters had a good discussion using signs, such as hand signals, pictures, and other cues to match the mindset. With discussion and emotional control from everyone, the two brothers will not decide to attack each other, such as hitting, even killing. Both characters should have an attitude of restraining emotions before acting that violates humanity. Therefore, the folklore "Kuburan Duo" contains individual moral values in the form of:

(1) The value of respecting and appreciating

(2) Fair and wise values

(3) The value of knowing retribution

(4) The value of caution in action.

2. Social Moral Values

Moral and social values are moral elements that bind one's relationship with others so that they can continue to live together. In the fairy tale "Kuburan Duo", two characters from different languages and cultures are told to experience communication misunderstandings due to language differences. Social moral values can be created if each character 
is able to apply individual moral values well. In other words, each character must have an individual attitude before they can live in harmony with others. The two characters in the folklore "Kuburan Duo" still do not have individual moral values so that social moral values still cannot be applied. The folklore "Kuburan Duo" teaches readers to be able to work together with family in various matters, one of which is looking for sustenance (work). This is illustrated by the cohesiveness of the two characters when hunting deer. Therefore, there are four social moral values taught by the folklore "Duo Graves":

1) The value of working together

2) Value of affection

3) The value of harmony

4) The value of caring for the fate of others

3. Religious Moral Values

Religious moral values are present as the application of the first Pancasila principle, namely Belief in One Supreme God. Through religious moral values, readers are expected to be able to realize the concept of God and religion. In the folklore "Kuburan Duo", both characters are expected to have religious awareness and obedience to God so as not to hurt each other, even to kill. The concept of religion seems to still not appear in the folklore "Kuburan Duo", such as religious teachings to contain emotions. Therefore, this fairy tale teaches the reader the importance of religion with the following values.

1) The value of surrendering to God

2) The value of asking God's forgiveness

\section{CONCLUSION}

The story raised above is a story or traditional folklore in Pasaman Regency. The folklore makes children aware of the importance of language culture to respect each other. How to make them aware to tolerate each other and get to know each other, the existence of sharing

If a story or folklore can be used as an education, it will be able to shape the character of children and deepen traditional stories, according to their age level. Ni 1 a i positives that can be lifted from the story if it rushed into the ethics of the positive value will also be instilled in children, especially for students of SMAN 1 LubukSikaping. And it could be the other way around if the stories or folklore they get are not on the right path it will have a negative impact on children's education and development.
Apart from stories or folklore, they can also contain values and can be of great benefit to the learning process of children at school and at home.

\section{REFERENCES}

[1] S. a. P. Sauri, "Preserving Pandeglang Regency Folklore and Its Utilization as Literary Appreciation Learning Materials," Jurnal Pendidikan, vol. 3, no. 2, pp. 31-40.

[2] T. D. Soelistyarini, "Children's Stories and Character Building," in Workshop on National Character Building through Children's Literature, 2011.

[3] R. Megawangi, Semua Berakar pada Karakter IsuIsu Permasalahan Bangsa, Jakarta: Fakultas Ekonomi Universitas Indonesia, 2007.

[4] J. Dananjaya, Folklor Indonesiai Ilmu Gosip Dongeng dan Lain-lain, Jakarta: Grafiti, 2007.

[5] Lizawati, "Cerita Rakyat Sebagai Sarana Pendidikan Karakter Dalam Membangun generasi Literat," Jurnal Sebasa, vol. 1, no. 1, 2018.

[6] I. Gojali, "Efektivitas Pendidikan Karakter Bangsa Melalui Dongeng Atau Cerita Rakyat Nusantara dengan Menggunakan Platform Android," Jurnal Widyaloka Ikip Widya Darma, vol. 4, no. 2, 2017.

[7] B. Suratman, "endidikan Karakter Anak Usia Dini Melalui Cerita Rakyat dan Bermain Singinca'an Pada Suku Melayu Sambas Desa Sepadu," in Proceedings of The 3rd Annual Conference on Islamic Early Childhood Education, Yogyakarta, 2018.

[8] Koentjaraningrat, Pengantar Ilmu Antropologi, Jakarta: Rineka Cipta, 2015.

[9] S. Kurniawan, "Pantang Larang dalam Pendidikan Karakter Pada Anak Usia Dini Orang Melayu Sambas Desa Sepinggan," in International Conference Proceeding, Pontianak, 2017.

[10] M. M. Amin, Pendidikan Karakter Anak Bangsa, Jakarta: Baduose Media, 2011. 
[11] Koentjaraningrat, Pengantar Ilmu Antropologi., Jakarta: Rineka Cipta, 2015.

[12] Sumiyati, "Keluarga Sebagai Sekolah Pertama Anak," in International Conference Proceeding, Pontianak, 2017.

[13] N. K. Ratna, Peranan Karya Sastra,Seni, dan Budaya dalam Pendidikan Karakter., Yogyakarta: Pustaka Pelaja, 2014.

[14] Sugiyono, Quantitative, Qualitative and R\&D Research Methods, Bandung: Alphabeta, 2015.

[15] D. Sulistyarni, "Moral Values in Folklore as a Means of Character Education," [Online]. Available: http://www.kosmaext2010.com/makalah-sosiologianthropologi-Pendidikan-concept-transmisi-changeculture-learning.php . 